\title{
Strategi Guru Aqidah Akhlak Dalam Mananamkan Karakter Peserta Didik di MI Wahid Hasyim
}

\author{
Muhammad Sufyan Ats Tsauri ${ }^{1}$, Seka Andrean ${ }^{2}$ \\ Pascasarjana Pendidikan Guru Madrasah Ibtidaiyah UIN Sunan Kalijaga \\ Yogyakarta ${ }^{1,2}$ \\ e-mail: sufyanatstsauri96@gmail.com ${ }^{1}$, sekaandrean28@gmail.com²
}

\begin{abstract}
Abstrak
Karakter merupakan nilai dasar yang membangun pribadi seseorang, terbentuk baik karena pengaruh hereditas maupun pengaruh lingkungan, yang membedakannya dengan orang lain, serta diwujudkan dengan sikap dan perilakunya dalam kehidupan sehari-hari. Dalam hal ini madrasah khususnya pembelajaran aqidah akhlak merealisasikannya dalam nilai-nilai agama Islam kepada peserta didik. Penelitian ini menggunakan metode kualitatif. Pengumpulan data dilakukan dengan observasi, wawancara, dan dokumentasi. Analisis data dilakukan dengan menganalisis semua data dari hasil penelitian, supaya dapat dijadikan satu kesatuan kemudian diverifikasi. Hasil penelitian menunjukkan bahwa: (1) perencanaan pembelajaran guru Aqidah Akhlak sebagai upaya penanaman karakter adalah dengan mendesain perencanaan pembelajaran dengan melibatkan media, (2) penerapan pembelajaran guru Aqidah Akhlak dalam upaya penanaman karakter siswa yang dilakukan telah mengacu pada tata tertib maupun aturan yang telah direncanakan dan ditetapkan dalam setiap kegiatan atau proses pembelajaran dalam lembaga pendidikan dasar.
\end{abstract}

Kata Kunci: Strategi Guru, Karakter, Pembelajaran Aqidah Akhlak. 


\section{PENDAHULUAN}

Pendidikan sekarang ini belum mampu untuk berperan sebagai transfer ilmu pengetahuan (transfer of knowledge) sekaligus sebagai transfer nilai (transfer of value). Sehingga banyak terjadi fenomena-fenomena dalam masyarakat yang dinilai tidak selaras dengan nilai-nilai moral dan etika. Dengan adanya fenomena-fenomena tersebut upaya pemerintah adalah dengan adanya program pendidikan karakter (Nur Dan Emi Sundari Hidayat, 2014, hlm. 94). Pendidikan karakter adalah suatu sistem penanaman nilai-nilai karakter yang baik kepada semua yang terlibat dan sebagai warga sekolah sehingga mempunyai pengetahuan, kesadaran, dan tindakan dalam melaksanakan nilai-nilai tersebut (Akhmad Muhaimin Azzet, 2011, hlm. 36).

Karakter merupakan nilai dasar yang membangun pribadi seseorang, terbentuk baik karena pengaruh hereditas maupun pengaruh lingkungan, yang membedakannya dengan orang lain, serta diwujudkan dalam sikap dan perilakunya dalam kehidupan sehari-hari. Sedangkan yang berkarakter adalah orang yang dapat merespon segala situasi secara bermoral dan dimanifestasikan dalam bentuk tindakan nyata melalui tingkah laku yang baik. Karakter sangat erat kaitannya dengan konsep moral (moral knowing), sikap moral (moral felling), dan perilaku moral (moral behavior) (Muchlas Samani And Hariyanto, M.S, 2011, hlm. 43).

Berdasarkan ketiga komponen diatas dapat dinyatakan bahwa karakter yang baik didukung oleh pengetahuan tentang kebaikan, bertingkah laku yang baik, dan melakukan perbuatan kebaikan.

Dalam kehidupan sehari-hari akhlak merupakan hal yang sangat penting dalam bertingkah laku. Dengan akhlak yang baik seseorang tidak akan terpengaruh pada hal-hal yang negatif. Dalam agama Islam telah diajarkan kepada semua pemeluknya agar dirinya menjadi manusia yang berguna bagi dirinya serta berguna bagi orang lain. Manusia yang berakhlak akan dapat menghiasi dirinya dengan sifat kemanusiaan yang sempurna, menjadi manusia shaleh dalam arti yang sebenarnya, selalu menjaga kualitas kepribadiannya sesuai dengan tuntunan Allah SWT dan Rasul-Nya.

Pembelajaran Akidah Akhlak merupakan mata pelajaran yang memiliki kontribusi besar dalam memberikan motivasi kepada peserta didik untuk mempelajari dan mempraktikkan akidahnya dalam bentuk pembiasaan untuk 
melakukan akhlak terpuji dan menghindari akhlak tercela dalam kehidupan seharihari. Al-akhlak al-karimah ini sangat penting untuk dipraktikkan dan dibiasakan oleh peserta didik dalam kehidupan individu, bermasyarakat dan berbangsa, terutama dalam rangka mengantisipasi dampak negatif dari era disrupsi dan krisis multidimensional yang melanda bangsa dan Negara Indonesia (Purniadi Putra, 2018, hlm. 151). Jadi, dalam penelitian ini, penulis hanya akan melakukan penelitian pada mata pelajaran Aqidah Akhlak.

Sementara itu, di MI Wahid Hasyim, Depok, Sleman, D.I Yogyakarta sebagai sekolah yang berasaskan agama Islam juga mempunyai problema dalam hal akhlak peserta didik. Misalnya, pembelajaran akhlak lebih fokus menghafal karakter bukan membiasakan karakter, akibatnya karakter atau akhlak yang diajarkan hanya dijadikan sebagai materi saja dan masih kurang dalam proses penerapannya. Dengan demikian, pendidikan akhlak sejak dini pada peserta didik sangatlah penting sekali agar peserta didik membiasakan diri dalam menerapkan hal-hal terpuji dalam kehidupan bermasyarakat baik pada saat masih usia sekolah maupun pada saat mereka besar nanti. Pembentukan karakter disini sangat ditekankan karena penanaman pribadi yang baik sejak dini akan memberikan dampak pada masa-masa selanjutnya.

Melihat permasalahan di atas, penulis tertarik untuk membahas dalam artikel ini dengan judul "Strategi guru aqidah akhlak dalam menanamkan karakter peserta didik di MI Wahid Hasyim”. Adapun fokus penelitian jurnal ini adalah (a) bagaimana strategi guru Aqidah Akhlak sebagai upaya penanaman karakter peserta didik di MI Wahid Hasyim? (b) bagaimana penerapan pembelajaran guru Aqidah Akhlak dalam upaya penanaman karakter siswa di MI Wahid Hasyim?

\section{Pendidikan Karakter}

Karakter berasal dari bahasa Yunani yang berarti "to mark" atau menandai atau memfokuskantata cara mengaplikasikan nilai kebaika dalam bentuk tindakan atau tingkah laku. Pengertian karakter menurut Pusat Bahasa Depdiknas adalah " bawaan, hati, jiwa, kepribadian, budi pekerti, perilaku, personalitas, sifat tabiat, temperamen, watak" (Hamdani Hamid 2013, hlm. 31).

Secara etimologis, kata karakter bisa bersifat tabiat, sifat-sifat kejiwaan, akhlak atau budi pekerti yang membedakan seseorang dengan orang lain, atau watak orang 
berkarakter memiliki watak, kepribadian, budi pekerti atau akhlak. Degan makna karakter indentik dengan kepribadian atau akhlak. Kepribadian merupakan ciri atau karakteristik atau sifat khas dari diri seseorang yang bersumber dari bentukanbentukan yang diterima ari lingkungan, misalnya keluarga pada masa kecil atau bawaan dari lahir (Zainal Aqib 2012, hlm. 118).

Pengertian secara khusus, karakter adalah nilai-nilai yang khas baik (tahu nilai kebaikan, mau berbuat baik, nyata berkehidupan baik, dan dampak baik terhadap lingkungan) yang terpatri dalam diri dan terwujud dalam prilaku. Karakter merupakan ciri khas seseorang atau sekelompok orang yang mengandung nilai, kemampuan, kapasitas moral, dan ketegaran dalam menghadapi kesulitan dan tantangan (Anas Salahudin and Irwanto Alkrienciehie 2013, hlm. 42.)

Pendidikan sebagai proses aktivitas atau kegiatan yang disengaja oleh masyarakat merupakan sebuah upaya agar membentuk, mengarahkan, dan mengatur manusia agar seperti yang diharapkan bersama. Undang-undang No 20 Tahun 2003 menjelaskan pendidikan adalah mewujudkan suasana belajar pembelajaran secara aktif, terencana dan perlu usaha sadar dalam menumbuhkan potensi serta kekuatan anak dalam bidang keagamaan, pengendalian diri, kecerdasan, karakter mulia atau akhlak mulia.

Pendidikan karakter di sekolah sebagai pembelajaran yang mengarah pada penguatan dan pengembangan perilaku anak secara utuh yang didasarkan pada suatu nilai tertentu yang dirujuk oleh sekolah. Jadi pendidikan karakter di sekolah mengandung makna:

Pendidikan karakter merupakan pendidikan yang terintegrasi dengan pembelajaran yang terjadi pada semua mata pelajaran.

Diarahkan pada penguatan dan pengembangan perilaku anak secara utuh. Asumsinya anak merupakan organisme manusia yang memiliki potensi untuk dikuatkan dan dikembangkan.

Penguatan dan pengembangan perilaku didasari oleh nilai yang dirujuk sekolah (lembaga) (Purniadi Putra, 2018, hlm. 147-56).

Tujuan pendidikan karakter di sekolah adalah: (Kesuma And Dharma, Dkk, 2011, hlm.5). 
Menguatkan dan mengembangkan nilai-nilai kehidupan yang dianggap penting dan perlu sehingga menjadi kepribadian atau kepemilikan peserta didik yang khas sebagaimana nilai-nilai yang dikembangkan.

Mengoreksi perilaku peserta didik yang tidak bersesuaian dengan nilai-nilai yang dikembangkan oleh sekolah.

Membangun koneksi yang harmoni dengan keluarga dan masyarakat dalam memerankan tanggung jawab pendidikan karakter secara bersama.

Pendidikan karakter kini memang menjadi isu utama dalam pendidikan. Selain menjadi bagian dari proses pembentukan akhlak anak bangsa, pendidikan karakter diharapkan mampu menjadi pondasi utama dalam meningkatkan derajat dan martabat bangsa Indonesia. Dalam lingkungan Kementerian Pendidikan Nasional sendiri, pendidikan karakter menjadi fokus pendidikan di seluruh jenjang pendidikan yang dibinannya.

Demoralisasi terjadi karena proses pembelajaran cenderung mengajarkan pendidikan moral dan budi pekerti sebatas teks dan kurang mempersiapkan siswa untuk menyikapi dan menghadapi kehidupan yang kontradiktif. Selain itu, pendidikan agama yang selama puluhan tahun dianggap sebagai salah satu media efektif dalam penginternalisasian karakter luhur terhadap anak didik (Agus Wibowo, 2012, hlm.55).

Dalam kenyataannya sekadar mengajarkan dasar-dasar agama. Bahkan ia semakin kehilangan perannya sebagai media mengantarkan siswanya untuk memahami dan mengamalkan ajaran agamanya.

\section{Pembelajaran Aqidah Akhlak}

Aqidah adalah bentuk masdar dari kata aqoda, ya'qidu, 'aqdan-, aqidatan yang berarti simpulan, ikatan, sangkutan, perjanjian dan kokoh. Sedang secara teknis aqidah berarti iman. Tugas pendidikan karakter selain mengajarkan mana nilai-nilai kebaikan dan mana nilai-nilai keburukan, justru yang ditekankan adalah langkahlangkah penanaman kebiasaan (habituation) terhadap hal-hal yang baik. Hasilnya, individu diharapkan mempunyai pemahaman tentang nilai-nilai kebaikan dan nilai keburukan, mampu merasakan nilai-nilai yang baik dan mau melakukannya kepercayaan dan keyakinan. Dan tumbuhnya kepercayaan tentunya di dalam hati, 
sehingga yang dimaksud aqidah adalah kepercayaan yang menghujam atau tersimpul di dalam hati (Andi Banna, 2019, hlm.8).

Aqidah diibaratkan sebagai pondasi bangunan. Sehingga aqidah harus dirancang dan dibangun terlebih dahulu dibandingkan bagian-bagian yang lain. Aqidah pun harus dibangun dengan kuat dan kkoh agar tidak mudah goyah yang akan menyebabkan bangunan menjadi runtuh. Bangunan yang dimaksud disini adalah islam yang benar, menyeluruh dan sempurna.

Berbicara mengenai aqidah tentunya tidak lengkap tanpa disertai akhlak. Akhlak adalah wujud realisasi dan aktualisasi diri dari aqidah sesorang. Akhlak berasal dari bahasa arab, yaitu bentuk jamak dari khulukun, yang artinya tabiat, budi pekerti, al'aadat yang artinya kebiasaan, al-muruu'ah yang artinya peradaban yang baik, dan ad-din yang berarti agama (Subahri, 2015). Sedangkan akhlak secara bahasa bermakna pembuatan atau penciptaan. Dalam konteks agama, akhlak bermakna perangai, budi, tabi'at, adab, atau tingkah laku (Ahmad Bangun Nasution And Rohani Hanun Sirega, 2013, hlm. 30).

Adapun nilai-nilai akhlak yang harus miliki bagi siswa sekolah dasar diantaranya adalah (1) memiliki akhlakul karimah yang meliputi: dislipin, hidup bersih, ramah, sopan-santun, syukur nikmat, hidup sederhana, rendah hati, jujur, rajin, percaya diri, kasih sayang, taat, rukun, tolong menolong, hormat dan patuh, amanah dan lain sebaginya; (2) menghindari akhlak tercela yang meliputi: berkata kotor, hidup kotor, bohong, sombong, malas, durhaka, khianat, iri, dengki dan lain sebagainya; (3) aspek adab Islami yang meliputi adab terhadap diri sendiri (adab makan, dan minum, mandi, tidur, buang air besar/ kecil, berbicara dan lain sebagainya (Efendi 2019).

Berdasar beberapa definisi di atas, pada hakikatnya akhlak ialah suatu kondisi atau sifat yang meresap dalam jiwa dan menjadi kepribadian. Dari sini keadaan gerak jiwa yang mendorong ke arah melakukan perbuatan dengan tidak memerlukan pikiran.

Dengan demikian pembelajaran aqidah akhlak adalah upaya sadar dan terencana dalam menyiapkan peserta didik untuk mengenal, memahami, menghayati dan mengimani kepada Allah SWT dan merealisasikannya dalam perilaku akhlak mulia dalam kehidupan sehari-hari berdasarkan Qur'an dan hadits melalui kegiatan 
bimbingan, pengajaran, latihan, serta penggunaan pengalaman. Dibarengi tuntutan untuk menghormati penganut agama lain dan hubungannya dengan kerukunan antar umat beragama dalam masyarakat hingga terwujud kesatuan dan persatuan bangsa.

\section{METODE PENELITIAN}

Metode penelitian yang digunakan pada penelitian ini yaitu metode penelitian kualitatif. Menurut Wina Sanjaya Penelitian kualitatif merupakan prosedur penelitian yang memberikan data deskriptif yaitu data tertulis dan data lisan dari subjek penelitian yang bisa diamati. Pemilihan metode kualitatif dalam penelitian ini karena lebih mudah berhadapan langsung dengan kenyataan yang dihadapi oleh peneliti di lapangan (Wina Sanjaya, 2013, hlm. 47). Selain itu metode kualitatif berhubungan langsung antara peneliti dengan informan serta lebih bisa menyesuaikan pada penajaman pengaruh dan pola-pola nilai yang ada (Moleong, Lexy J. 2017, hlm. 7).

Sumber data dalam penelitian ini sebagian besar menggunakan data kualitatif yaitu diperoleh dari narasumber, tempat, kegiatan atau aktivitas, dan dokumentasi. Berdasarkan metode penelitian kualitatif teknik pengumpulan data dalam penelitian ini yaitu 1) wawancara yang bersifat terbuka dan dilakukan secara berulang-ulang kepada informan yang sama. 2) observasi berguna dalam menggali data dari berbagai sumber data antara lain tempat penelitian, peristiwa yang terjadi, dan rekaman gambar. 3) pencatatan dokumen berguna untuk melengkapi data saat melaksanakan wawancara dan observasi. 4) analisis dokumen berguna untuk mengumpulkan data dokumen sebagai sumber data untuk menafsirkan, menguji.

Analisis data dalam penelitian kualitatif bersifat induktif yaitu penarikan simpulan bersifat umum dari data-data dilapangan. Penelitian ini menggunakan analisis model interaktif. Model analisis interaktif yaitu sebagai berikut: (Sugiyono 2017)

Reduksi data dengan cara seleksi, klasifikasi, dan memfokuskan data lapangan.

Penyajian data dengan deskripsi data-data sesuai dengan pokok masalah Penarikan simpulan dengan mengambil kesimpulan berdasarkan reduksi dan penyajian data. 


\section{HASIL DAN PEMBAHASAN}

Sesuai dengan hasil observasi dan wawancara peneliti di MI Wahid Hasyim, Depok, Sleman, D.I Yogyakarta, bahwa perencanaan pembelajaran Aqidah Akhlak dalam pendidikan karakter ini ada beberapa yang harus diperhatikan antara lain: (1) merancang perencanaan pembelajaran berdasarkan kurikulum yaitu berpedoman pada silabus dan RPP, (2) dalam perencanaan pembelajaran Aqidah Akhlak harus memperhatikan pemilihan bentuk pembelajaran yang disesuaikan dengan kondisi, karakteristik dan kemampuan siswa, agar pembelajaran berlangsung sesuai tujuan yang diharapkan.

Perencanaan pembelajaran Aqidah Akhlak yang dibuat oleh guru adalah penyusunan perencanaan strategi guru dalam menerapkan karakter kerpada siswa dan penggunaan media pembelajaran dan bentuk belajar yang berdasarkan pada tujuan. Di mana tujuan pembelajaran itu selain dapat menambah ilmu pengetahuan dari siswa itu sendiri, tetapi juga dapat mengubah perilaku mereka agar menjadi pribadi yang lebih baik. Ini mengacu pada pengertian belajar yang dikemukakan oleh Kimble dan Garmezi bahwa belajar adalah perubahan tingkah laku yang relatif permanen yang terjadi sebagai hasil dari pengalaman. Untuk itu perencanaan yang disusun oleh guru disesuaikan dengan kondisi, karakteristik dan kemampuan siswa, akan tetapi tetap berpedoman pada kurikulum pembelajaran yaitu berdasarkan pada silabus dan RPP.

Dengan dilakukannya perencanaan yang disusun oleh guru maka proses pembelajaran akan berjalan sesuai dengan tujuan yang diharapkan, yaitu siswa mampu menguasai materi dan mereka dapat menerapkan materi yang disampaikan dalam kehidupan siswa sehari-hari sehingga terbentuklah karakter yang baik. Di dalam sebuah perencanaan tidak terlepas dari media, strategi dan pengkondisian suasana kelas yang dilakukan oleh guru saat proses pembelajaran berlangsung. Peran guru di sini adalah sebagai fasilitator dan motivator bagi siswanya. Untuk itu peran guru sangat berpengaruh dalam pembentukan karakter siswa. Untuk itu, guru harus mampu membuat perencanaan pembelajaran yang berkualitas dan semenarik mungkin, agar para siswa termotivasi untuk lebih baik dalam meningkatkan belajarnya. 
Penerapan pembelajaran Aqidah Akhlak mengacu pada tata tertib maupun aturan yang telah ditetapkan dalam setiap kegiatan atau proses pembelajaran dalam suatu lembaga pendidikan, di antaranya proses pembelajaran dengan mengacu pada kurikulum maupun silabus dari masing-masing materi pelajaran yang telah ditetapkan oleh pemerintah. Sehingga dari pihak sekolah tinggal mengolah, membuat program atau rencana pembelajaran Aqidah Akhlak dengan tetap mengacu pada kurikulum maupun silabus yang ada.

Penerapan pembelajaran Aqidah Akhlak ini ditujukan pada pembentukan karakter siswa. Siswa tidak hanya memperdalam dari segi keintelektualannya saja, akan tetapi juga pada karakter atau pribadi siswa. Untuk itu dalam penerapannya guru harus mampu memberikan pembelajaran yang bermakna saat proses pembelajaran berlangsung. Guru menggunakan berbagai macam sumber belajar dengan mengaitkannya dengan materi yang dipelajari. Selain itu keaktifan siswa dalam proses pembelajaran juga harus diperhatikan karena ini dapat dijadikan ukuran guru sejauh mana siswa mampu memahami materi Aqidah Akhlak. Pembelajaran secara konsepsional ini memiliki beberapa implikasi. Pertama, perlu diusahakan agar proses pembelajaran yang dilakukan berlangsung secara interaktif antara siswa dengan sumber belajar yang direncanakan. Kedua, bagi siswa, dalam pembelajaran dapat berlangsung interaksi internal yang melibatkan seluruh potensi yang dimilikinya dengan sumber belajar. Sumber belajar sendiri cukup beragam; (1) nilainilai yang ada dalam mata pelajaran yang sedang diajarkan; (2) guru yang berfungsi sebagai fasilitator; (3) bahan ajar cetak maupun non cetak; (4) media dan alat yang dipakai belajar; (5) cara dan teknik belajar yang dikembangkan; (6) kondisi lingkungan (sosial, budaya, spiritual, dan alam) yang menghasilkan perubahan tingkah laku siswa ke arah yang lebih baik.

Ketiga, dalam proses itu juga terbuka peluang untuk memilih, menetapkan, dan mengembangkan metode pembelajaran yang memiliki peluang paling baik bagi tercapainya tujuan dalam proses pembelajaran ini pun mengacu pada pendapat dari Marzuki bahwa karakter identik dengan akhlak, sehingga karakter merupakan nilainilai perilaku manusia yang universal yang meliputi seluruh aktivitas manusia, baik dalam rangka berhubungan dengan Tuhan, dengan diri sendiri, dengan sesama manusia, maupun dengan lingkungan, yang terwujud dalam pikiran, sikap, perasaan, 
perkataan, dan perbuatan berdasarkan norma-norma agama, hukum, tata krama, budaya, dan adat istiadat (Marzuki 2015, hlm. 11). Telah dijelaskan bahwa di dalam pendidikan karakter itu terdapat nilai-nilai yang terkandung di dalamnya dan hal tersebut harus benar-benar bisa ditanamkan pada semua siswa di sekolah.

Hal tersebut menunjukkan bahwa penanaman karakter melalui pembelajaran Aqidah Akhlak yang dilakukan oleh guru mata pelajaran di lokasi penelitian tersebut membuahkan hasil. Dengan demikian melalui pembelajaran Aqidah Akhlak dapat menanamkan karakter kepada siswa yang telah direncanakan secara efektif dan efisien.

\section{KESIMPULAN}

Berdasarkan hasil penelitian yang disimpukan ini dikemukakan beberapa implikasi yang dianggap relevan dengan penelitian, antara lain sebagai berikut.

Perencanaan pembelajaran guru Aqidah Akhlak sebagai upaya penanaman karakter adalah dengan mendesain perencanaan pembelajaran dengan melibatkan media dan menggunakan strategi yang menyenangkan. Rancangan perencanaan dalam penyampaian pembelajaran Aqidah Akhlak yang dibuat oleh guru adalah penyusunan perencanaan penggunaan media pembelajaran dan bentuk belajar yang berdasarkan pada tujuan. Dalam memilih media dan metode pembelajaran, pada dasarnya prinsip yang digunakan guru adalah efektifitasnya dalam mencapai tujuan pembelajaran. Rancangan bentuk belajar di kelas yang dirancang guru adalah untuk menciptakan kondisi agar siswa dapat belajar dengan penuh motivasi.

Penerapan pembelajaran guru Aqidah Akhlak dalam upaya pembentukan karakter siswa yang dilakukan telah mengacu pada tata tertib maupun aturan yang telah direncanakan dan ditetapkan dalam setiap kegiatan atau proses pembelajaran di suatu lembaga pendidikan. Penyampaian pembelajaran Aqidah akhlak dalam menanamkan karakter siswa yang diterapkan oleh guru mata pelajaran di lokasi penelitian tersebut membuahkan hasil. Dengan demikian media dan metode yang digunakan dalam penyampaian pembelajaran dapat digunakan sebagai upaya meningkatkan prestasi belajar siswa dan sebagai 
upaya untuk membentuk pembiasaan karakter siswa yang baik terutama pada pada mata pelajaran Aqidah Akhlak.

\section{DAFTAR PUSTAKA}

Agus Wibowo. 2012. Pendidikan Karakter: Strategi Membangun Karakter Bangsa Berperadaban. Yogyakarta: Pustaka Belajar.

Ahmad Bangun Nasution, and Rohani Hanun Siregar. 2013. Akhlak Tasawuf Pengenalan, Pemahaman, Dan Pengaplikasiannya (Disertai Biografi TokohTokoh Sufi). Cet 1. Jakarta: PT RajaGrafindo Persada.

Akhmad Muhaimin Azzet. 2011. Urgensi Pendidikan Karakter Di Indonesia. Yogyakarta: Ar-Ruzz Media.

Anas Salahudin, and Irwanto Alkrienciehie. 2013. Pendidikan Karakter Pendidikan Berbasis Agama \& Budaya. Bandung: CV Pustaka Setia.

Andi Banna. 2019. "IMPLEMENTASI PENDIDIKAN KARAKTER DALAM PEMBELAJARAN AQIDAH AKHLAK Jurnal Ilmiah Islamic Resources." 2019. http://jurnal.fai.umi.ac.id/index.php/islamicresources/article/view/7/6.

Efendi, Didik. 2019. "Proses Pembentukan Aqidah Dan Akhlak Pada Siswa Sekolah Dasar Di Kota Jayapura.” Al-Adzka: Jurnal Ilmiah Pendidikan Guru Madrasah Ibtidaiyah 9 (1): 9-20. https://doi.org/10.18592/aladzkapgmi.v9i1.2814.

Hamdani Hamid. 2013. Pendidikan Karater Perspektif Islam. Bandung: Pustaka Setia.

Hidayat, Nur dan Emi Sundari. 2014. "INTEGRASI NILAI KARAKTER PEDULI LINGKUNGAN HIDUP DALAM PEMBELAJARAN AKIDAH AKHLAK DI MI Nur.” AL-BIDAYAH: Jurnal Pendidikan Dasar Islam 06: 93-112.

Kesuma, and Dharma, dkk. 2011. Pendidikan Karakter Kajian Teori Dan Praktek Di Sekolah. Bandung: PT Remaja Rosdakarya.

Marzuki. 2015. Pengintegrasian Pendidikan Karakter Dalam Pembelajaran Di Sekolah. Yogyakarta: FIS Universitas Negeri Yogyakarta.

Moleong, Lexy J. 2017. "Metodologi Penelitian Kualitatif (Edisi Revisi)." (Bandung: PT. Remaja Rosdakarya). 2017.

Muchlas Samani, and Hariyanto, M.S. 2011. Konsep Dan Model Pendidikan Karakter. Bandung: PT Remaja Rosdakarya.

Putra, Purniadi. 2018a. "Implementasi Pendidikan Karakter Dalam Pembelajaran Aqidah Akhlak (Studi Multi Kasus Di MIN Sekuduk Dan MIN Pemangkat Kabupaten Sambas)." Al-Bidayah: Jurnal Pendidikan Dasar Islam 9 (2): 14756. https://doi.org/10.14421/al-bidayah.v9i2.14. 
2018b. "Implementasi Pendidikan Karakter Dalam Pembelajaran Aqidah Akhlak (Studi Multi Kasus di MIN Sekuduk dan MIN Pemangkat Kabupaten Sambas)." Al-Bidayah: Jurnal Pendidikan Dasar Islam 9 (2): 147-56. https://doi.org/10.14421/al-bidayah.v9i2.14.

Subahri. n.d. "AKTUALISASI AKHLAK DALAM PENDIDIKAN Islamuna: Jurnal Studi Islam. Vol. 2. No. 2. (5 Desember 2015)." Accessed March 26, 2020. http://ejournal.stainpamekasan.ac.id/islamuna/article/view/660.

Sugiyono. 2017. Metode Penelitian Pendidikan Pendekatan, Kuantitatif, Kualitatif Dan $R \& D$. Bandung: Alfabeta.

Wina Sanjaya. 2013. Penelitian Pendidikan: Jenis, Metode, Dan Prosedur. Jakarta: Kencana.

Zainal Aqib. 2012. Pendididkan Karakter Di Sekolah Membangun Karakter Dan Kepribadian Anak. Bandung: CV Yrama Media. 